\title{
Assessment of an Alternative IPM Program for the Production of Apples for Processing
}

\author{
Alan R. Biggs, Professor of Plant Pathology, and Henry W. Hogmire, Professor of Entomology, West Virginia \\ University, Kearneysville Tree Fruit Research and Education Center, P.O. Box 609, Kearneysville, 25430; and Alan \\ R. Collins, Agricultural Economist, West Virginia University, Division of Resource Management, P.O. Box 6108, \\ Morgantown, 26506
}

\begin{abstract}
Biggs, A. R., Hogmire, H. W., and Collins, A. R. 2000. Assessment of an alternative IPM program for the production of apples for processing. Plant Dis. 84:1140-1146.

Conventional and alternative integrated pest management (IPM) programs for managing arthropods and diseases affecting processing apple production were compared over 4 years. The effects of the two programs on populations of pest and beneficial insects, and on disease incidence and severity, were evaluated in the field and laboratory and at a commercial fruit processing plant by federal inspectors. The economic implications of the alternative management program were assessed by examining its relative costs and benefits compared with conventional management. In the alternative program, arthropods were managed with oil and Bacillus thuringiensis $(\mathrm{Bt})$, and early-season diseases were managed with fungicides. Calcium chloride was used to suppress rot diseases. The alternative plots showed lower levels of indirect pests (aphids, leafhoppers, and mites) and increased numbers of arthropod natural enemies. On harvested fruit, there was significantly more injury in the alternative plots from codling moth or oriental fruit moth, plum curculio, and apple maggot. Levels of foliar diseases were similar between treatments; however, fruit from the alternative program exhibited significantly more sooty blotch, flyspeck, and rots. At the commercial processor, levels of cull fruit were higher for the alternative program in 2 of the 3 years with harvestable yield. Loads of fruit that were not acceptable for processing were due mostly to internal worms and worm damage. Incidence of decay was within the quality limits set by the processor, except for one conventional sample, in which decay exceeded 5\%. Of the 36 loads of fruit that were examined from each program, 4 and 13 loads were rejected from the conventional and alternative programs, respectively. Net present value comparisons were dependent upon how rejected loads were valued. At cider prices for rejected loads, net returns were similar between programs. When rejected loads were valued at a complete loss, conventional net present value was over 140\% higher than the alternative program. Among cultivars, Golden Delicious was most profitable and York was least profitable.
\end{abstract}

The mid-Atlantic apple-growing region (Virginia, West Virginia, Maryland, and Pennsylvania) contains about 23,000 ha of apple, 3,200 of which are located in West Virginia. In 1995, West Virginia ranked eighth among states in dollar value, with over $\$ 17$ million of apple production. Approximately $75 \%$ of the fruit production in West Virginia goes to the processing market; this represents about half of the value of apple production (15). Because most processing apples can be marketed with

Corresponding author: A. R. Biggs

E-mail: abiggs2@wvu.edu

This work was supported by grants from the West Virginia Tree Fruit Assessment Board, the State Horticultural Association of Pennsylvania, the USDA National Research Initiative, and the USDA Integrated IPM Special Grants Program. Scientific article 2744 of the West Virginia Agricultural and Forestry Experiment Station.

Accepted for publication 5 July 2000.

Publication no. D-2000-0825-01R

(C) 2000 The American Phytopathological Society higher levels of insect and disease injury than would be acceptable for fresh market fruit, reductions in pesticide use can be a realistic management recommendation that may have substantial impacts.

Integrated orchard management programs offer the potential to reduce effects on the environment while increasing net income to growers. The objectives of the research reported herein were to (i) compare conventional and alternative integrated pest management programs for arthropods and diseases on processing apples and evaluate the effects of the two programs on populations of pest and beneficial insects, and on disease incidence and severity; and (ii) evaluate the economics of the alternative management program by examining its relative costs and benefits compared with conventional management. Prior to this report, we evaluated two rotation crop systems for their impact on plant-parasitic nematode populations, nematode biocontrol agents, and soil structure and fertility (5). Also, we have reported on early tree growth, nitrate mobility, and pest and pathogen populations (3).

\section{MATERIALS AND METHODS}

Study site. The study site and treatments employed at the West Virginia University Kearneysville Tree Fruit Research and Education Center (WVU-KTFREC) have been described in detail elsewhere $(3,5)$. The experiment was arranged as a randomized block, split-plot design with the two management programs as whole plot treatments (three replicates) and four apple cultivars as subplot treatments. A Kentucky-31 (K-31) tall fescue (Festuca arundinacea) sod, seeded at $28.2 \mathrm{~kg}$ of seed/ha, was established in the alternative plots in May 1990. The sod was maintained for two growing seasons to increase soil organic matter and to favor development of nematode-suppressive soils. Conventional plots were disked and planted to corn in May 1990 and 1991, and received fertilizer, nematicide, and herbicide treatments. In April 1992, before planting the trees, the sod was killed with the herbicide glyphosate $(2.3 \mathrm{~kg}$ a.i./ha) in the tree rows of alternative plots. Alleys in the conventional plots were planted with K-31 and a herbicide-treated, 2.4-m-wide strip was maintained under the trees.

Each of the subplots was planted in April 1992 with one of four apple cultivars (York, Golden Delicious, Liberty [resistant to apple scab], or Fuji) on M.26 rootstock. Trees were established at 2.5 by $5.5 \mathrm{~m}$, with every 10th tree a pollinating cultivar that included Jonafree (early, midseason bloom), Gala (early, midseason bloom), and Braeburn (midseason, late bloom), each on M.9 EMLA rootstock (135 trees/subplot). Trees were trained according to the West Virginia slender spindle system (1). Soil type at the WVUKTFREC is Hagerstown silt loam (mixed mesic, Typic Hapludalf).

Pest and disease management programs. Prior to 1995, the same pesticide treatments were followed in the alternative and conventional management programs. From 1995 through 1998, pesticide treatments differed between the two programs as described below. All pesticides in both programs in all years were applied at 50\% of the recommended per-acre label rates, based on tree-row-volume calculations (7).

Control programs were applied to the alternative and conventional plots (Table 1). Early-season fungicide sprays were similar between programs and were based 
on the integrated, reduced spray program developed by Wilcox et al. (16). In the cover spray program, the conventional plots received calcium chloride at 3.4 $\mathrm{kg} / \mathrm{ha}$ (for management of bitter pit, a calcium-related nutritional disorder) plus fungicides (Ziram $76 \mathrm{DF}$ and Topsin-M $70 \mathrm{~W}$ ) and alternative plots received only calcium chloride at $6.7 \mathrm{~kg} / \mathrm{ha}$. Cultural treatments to reduce pathogen inoculum and pest incidence implemented in the alternative program included raking leaves and prunings into the middle of the rows and flail mowing in February of each year for reduction of apple scab and rot disease inoculum; and weekly removal of abscised fruit from the orchard floor beginning in August for reduction of inoculum of rot diseases and internal worms. Removal of abscised fruit from the orchard floor was not done in 1997 and 1998 due to the in- tensive labor requirements. The biological insecticide Bacillus thuringiensis (Bt) and oil (Damoil, Drexel Chemical Co., Memphis, TN) were used in the alternative program for insect control. Bt has low mammalian toxicity and is safe to beneficial insects. The 1998 programs were similar to previous years, with the exception that the Bt product Dipel was used instead of Biobit. In 1998, Biobit was no longer marketed for fruit. Mating disruption, a commercially available option for codling moth, was not used in the alternative program because of the small plot size $(0.8$ ha). Fire blight, caused by Erwinia amylovora, was managed similarly across treatments to minimize the potential for tree mortality in highly susceptible cultivarrootstock combinations. Agricultural streptomycin was applied when needed, as determined by the Maryblyt model (14).
Arthropod pest and natural enemy data collection. Incidence of foliagefeeding arthropod pests was determined at various times (Table 2) during the 1995 to 1998 growing seasons on each of five trees per cultivar per main plot. The abundance of white apple leafhopper and rose leafhopper was measured by counting the number of nymphs on the undersides of 25 leaves/tree. Rosy apple aphid was evaluated by counting the number of colonies and the number of injured leaf clusters per tree. Spirea aphid populations were determined by counting the number of aphids on the most infested leaf on each of five terminals per tree. Injury from oriental fruit moth larvae was evaluated by counting the total number of injured terminals per tree. Abundance of European red mite was quantified by sampling 20 leaves/tree, removing mites with a mite-brushing ma-

Table 1. Pest and disease control programs in alternative and conventional management programs, 1995 to 1998

\begin{tabular}{|c|c|c|c|}
\hline \multirow[b]{2}{*}{ Growth stagey } & \multirow[b]{2}{*}{ Target organisms ${ }^{\mathrm{z}}$} & \multicolumn{2}{|l|}{ Chemicals applied $^{x}$} \\
\hline & & Conventional & Alternative \\
\hline Dormant & ERM, A & & Oil \\
\hline Green tip & $\mathrm{FB}, \mathrm{A}, \mathrm{ERM}$ & Copper, oil, esfenvalerate & Copper \\
\hline Tight cluster & $\mathrm{S}, \mathrm{M}, \mathrm{R}, \mathrm{ERM}$ & Myclobutanil, mancozeb & Myclobutanil, mancozeb, oil \\
\hline Pink & $\mathrm{S}, \mathrm{M}, \mathrm{R}$ & Myclobutanil, mancozeb & Myclobutanil, mancozeb \\
\hline Petal fall & S, M, R, LR, OFM, PC, ERM & Myclobutanil, mancozeb, azinphosmethyl & Myclobutanil, mancozeb, Bt, oil \\
\hline First cover & $\mathrm{S}, \mathrm{M}, \mathrm{R}, \mathrm{PC}, \mathrm{ERM}, \mathrm{CM}$ & Myclobutanil, mancozeb, azinphosmethyl & Myclobutanil, mancozeb, Bt, oil \\
\hline Second cover & S, R, LR, ERM, CM, RT, BP & Mancozeb, ziram, methyl parathion, $\mathrm{CaCl}_{2}$ & $\mathrm{Bt}$, oil, $\mathrm{CaCl}_{2}$ \\
\hline Third cover & LR, LH, RT, BP & Ziram, thiophanate-methyl, methyl parathion, imidacloprid, $\mathrm{CaCl}_{2}$ & $\mathrm{Bt}$, oil, $\mathrm{CaCl}_{2}$, imidacloprid \\
\hline Fourth cover & OFM, RT, BP & Ziram, thiophanate-methyl, methyl parathion, $\mathrm{CaCl}_{2}$ & $\mathrm{Bt}, \mathrm{CaCl}_{2}$ \\
\hline Fifth cover & CM, OFM, RT, BP & Ziram, thiophanate-methyl, azinphosmethyl, $\mathrm{CaCl}_{2}$ & $\mathrm{Bt}, \mathrm{CaCl}_{2}$ \\
\hline Sixth cover & LR, CM, JB, RT, BP & Ziram, thiophanate-methyl, methyl parathion, $\mathrm{CaCl}_{2}$ & $\mathrm{Bt}, \mathrm{CaCl}_{2}$ \\
\hline Seventh cover & CM, OFM, LR, LH, RT, BP & Ziram, thiophanate-methyl, methyl parathion, imidacloprid, $\mathrm{CaCl}_{2}$ & $\mathrm{Bt}, \mathrm{CaCl}_{2}$ \\
\hline Eight cover & CM, OFM, LR, RT, BP & Ziram, thiophanate-methyl, azinphosmethyl, $\mathrm{CaCl}_{2}$ & $\mathrm{Bt}, \mathrm{CaCl}_{2}$ \\
\hline Ninth cover & $\mathrm{RT}, \mathrm{BP}$ & $\ldots$ & $\mathrm{CaCl}_{2}$, NuFilm 17 \\
\hline
\end{tabular}

$\mathrm{x} \mathrm{Bt}=$ Bacillus thuringiensis. Streptomycin was applied in some years to both programs during the bloom stage for control of fire blight. Imidacloprid applied at third cover to both programs was for control of potato leafhopper, and was used to minimize the potential transmission of fire blight bacteria.

y All spray applications made at 700 liters/ha except those at dormant and green tip stages, which were at 1,876 liters/ha (dilute). Ninth cover was applied only to cvs. Fuji and York in the alternative program.

z $\mathrm{A}=$ aphids, $\mathrm{S}=$ apple scab, $\mathrm{M}=$ powdery mildew, $\mathrm{R}=$ rusts, $\mathrm{PC}=$ plum curculio, $\mathrm{LR}=$ leafrollers, $\mathrm{OFM}=$ oriental fruit moth, $\mathrm{CM}=$ codling moth, $\mathrm{BP}=$ bitter pit, RT = summer rot complex; LH = leafhoppers; ERM = European red mite; JB = Japanese beetle.

Table 2. Incidence of arthropod pests and injury on leaves from trees in alternative and conventional management programs, 1995 to $1998^{\mathrm{x}}$

\begin{tabular}{|c|c|c|c|c|c|c|c|c|c|}
\hline \multirow[b]{2}{*}{ Year, treatment } & \multicolumn{4}{|c|}{ Early to late June } & \multirow{2}{*}{$\begin{array}{c}\text { Early July } \\
\text { OFM }\end{array}$} & \multirow{2}{*}{$\frac{\text { Late July }}{\text { ERM }^{\mathbf{z}}}$} & \multicolumn{2}{|c|}{ Early August } & \multirow{2}{*}{$\begin{array}{c}\text { Late August } \\
\text { WALH \& RLH }\end{array}$} \\
\hline & RAA & $\mathbf{S A}^{\mathbf{y}}$ & NE & WALH & & & STLM & JB & \\
\hline \multicolumn{10}{|l|}{1995} \\
\hline Alternative & $0.5 \mathrm{a}$ & $3.0 \mathrm{~b}$ & $\ldots$ & $4.9 \mathrm{a}$ & $\ldots$ & $0.6 \mathrm{a}$ & $\ldots$ & $2.3 \mathrm{a}$ & $36.4 \mathrm{a}$ \\
\hline $\begin{array}{l}\text { Conventional } \\
1996\end{array}$ & $0.0 \mathrm{a}$ & $8.4 \mathrm{a}$ & $\ldots$ & $5.2 \mathrm{a}$ & $\ldots$ & $1.1 \mathrm{a}$ & $\ldots$ & $1.7 \mathrm{a}$ & 49.9 a \\
\hline Alternative & $\ldots$ & $2.0 \mathrm{~b}$ & $0.49 \mathrm{a}$ & $3.6 \mathrm{~b}$ & $0.7 \mathrm{a}$ & $0.6 \mathrm{~b}$ & $1.7 \mathrm{~b}$ & $2.4 \mathrm{a}$ & $4.6 \mathrm{~b}$ \\
\hline $\begin{array}{l}\text { Conventional } \\
1997\end{array}$ & $\cdots$ & $6.4 \mathrm{a}$ & $0.18 \mathrm{~b}$ & $9.7 \mathrm{a}$ & $0.4 \mathrm{a}$ & $3.6 \mathrm{a}$ & $7.7 \mathrm{a}$ & $3.5 \mathrm{a}$ & $7.8 \mathrm{a}$ \\
\hline Alternative & $1.1 \mathrm{a}$ & $12.0 \mathrm{~b}$ & $\ldots$ & $1.7 \mathrm{~b}$ & $\ldots$ & $1.0 \mathrm{~b}$ & $0.5 \mathrm{a}$ & $1.2 \mathrm{a}$ & $1.2 \mathrm{a}$ \\
\hline $\begin{array}{l}\text { Conventional } \\
1998\end{array}$ & $0.5 \mathrm{a}$ & $168.3 \mathrm{a}$ & $\cdots$ & $4.4 \mathrm{a}$ & $\ldots$ & $2.0 \mathrm{a}$ & $0.8 \mathrm{a}$ & $0.2 \mathrm{~b}$ & $0.2 \mathrm{a}$ \\
\hline Alternative & $\ldots$ & $15.2 \mathrm{~b}$ & $3.4 \mathrm{a}$ & $0.5 \mathrm{~b}$ & $\ldots$ & $0.1 \mathrm{~b}$ & $\ldots$ & $\ldots$ & $\ldots$ \\
\hline Conventional & $\ldots$ & $89.0 \mathrm{a}$ & $1.1 \mathrm{~b}$ & $5.2 \mathrm{a}$ & $\ldots$ & $7.3 \mathrm{a}$ & $\ldots$ & $\ldots$ & $\ldots$ \\
\hline
\end{tabular}

${ }^{x}$ RAA = rosy apple aphid, colonies/tree; $\mathrm{SA}=$ spirea aphid, number per most infested leaf/terminal; NE = number of natural enemies per terminal (in 1996, ladybird beetles, green lacewing, and minute pirate bug; in 1998, ladybird beetles, aphid midge, syrphid fly, and green lacewing); WALH = white apple leafhopper, number per 25 leaves; RLH = rose leafhopper, number per 25 leaves; ERM = European red mite, number per leaf; JB = Japanese beetle, tissue consumed in grams per $100 \mathrm{~g}$ of leaves; OFM = oriental fruit moth, number of injured terminals/tree; STLM = spotted tentiform leafminer, number of mines observed in 5 min. Each value is the mean of 60 trees. Different letters in columns denote significant differences according to paired $t$ tests $(P<0.05)$.

y Each value is the mean of five terminals per tree.

${ }^{\mathrm{z}}$ Each value is the mean of 20 leaves per tree. 
chine, and counting motile stages with a binocular microscope. Injury from spotted tentiform leafminer was assessed by counting the total number of tissue-feeding mines observed on each tree in $5 \mathrm{~min}$. Japanese beetle injury was determined by selecting the 10 terminals with the most feeding damage on each tree. The 10 most damaged leaves on each of these terminals were collected. In a similar fashion, 100 undamaged leaves were collected from each of five trees per cultivar per main plot. All leaves were placed in brown-labeled paper bags, air dried for 2 months in a greenhouse, and weighed. Leaf tissue consumed by Japanese beetle was then determined by subtracting the dry weight of injured leaf samples from healthy samples for each cultivar. The incidence of injury to fruit from arthropod pests was determined by sampling 100 fruit/cultivar/main plot at normal harvest for each cultivar in 1995, 1997, and 1998 (there were no fruit to evaluate in 1996 because of a spring freeze). Fruit samples were placed in refrigerated storage and evaluated in the laboratory for injury by tufted apple bud moth, redbanded leafroller, codling moth, oriental fruit moth, tarnished plant bug, plum curculio, and apple maggot.

Incidence of natural enemies was determined in June 1996 and 1998 by counting the number on each of 5 terminals per tree. Natural enemies assessed in 1996 included ladybird beetles, green lacewings, and minute pirate bug; and, in 1998, included ladybird beetles, aphid midges, syrphid flies, and green lacewings.

Disease data collection. Foliar disease incidence was determined in June and September of each year by counting the total number of leaves and the number of leaves with scab, mildew, and cedar-apple rust symptoms from five terminal shoots on each of 10 randomly selected trees per cultivar per main plot in 1995, and from 10 terminal shoots per tree in subsequent years. One hundred fruit per cultivar per main plot were collected at harvest and evaluated in the laboratory for incidence and severity of apple scab, sooty blotch, flyspeck, and rots. Rots were categorized as a group and included all symptoms known to be caused by Colletotrichum gloeosporioides, C. acutatum, Botryosphaeria obtusa, and B. dothidea. Disease severity was determined for apple scab by counting the number of lesions per fruit. For sooty blotch, flyspeck, and rots, fruit were rated on a 1-to- 6 scale, with $1=1$ to $10 \%, 2=11$ to $25 \%, 3=26$ to $50 \%, 4=51$ to $75 \%, 5=76$ to $90 \%$, and $6=91$ to $100 \%$ of fruit surface area affected.

Processor evaluation. At harvest, approximately $41 \mathrm{~kg}$ (2 bushels) of fruit per cultivar per main plot were collected from 10 predetermined trees. Every fruit was collected from the first tree and placed in one of two wooden bushel crates. Collec- tion of fruit proceeded from as many as 10 trees until the two bushel crates were filled. Harvested fruit were taken the same day to Knouse Foods Cooperative, Inc., in Inwood, WV, where they were evaluated by certified United States Department of Agriculture (USDA) fruit inspectors. Inspection certificates were prepared for fruit from each of the 24 experimental units. Fruit were graded as US No. 1L (2.75 inches and larger), US No. $1 \mathrm{M}$ (2.5 to 2.75 inches), US No. $1 \mathrm{~S}$ (2.25 to 2.5 inches), US No. 2, ciders, and culls. For fruit graded as culls, the presence of live worms, worm holes, or decay was noted on the certificates; however, the individual cull factors were not separated. Criteria for rejection of fruit included the presence of live worms or incidence of active decay greater than $5 \%$.

Data and economic analyses. Pest and disease data were analyzed with analysis of variance (SAS Institute, Cary, NC). Percentage data were analyzed and means separated based on the square root of the arcsine transformation, although actual data are presented in the tables. Because our main objective was the design of management programs for orchards composed of different cultivars, analysis of variance interaction terms were evaluated at the $1 \%$ level of significance and main effect means (cultivar and management program) were evaluated at the 5\% level of significance. Main effect means for management treatments were compared with paired $t$ tests.

Apple yield data were available for years 4 through 7 of tree growth (1995 through 1998). A complete crop failure due to late spring frost in 1996 destroyed all apple production in this research. In 1997, a spring freeze limited yield, and in 1998, a severe worm infestation resulted in threefourths of the loads for the alternative crop being rejected by the processor. Utilizing available yield data from each management program and cultivar, gross revenues per hectare were computed by a summation of yield multiplied by apple prices offered to mid-Atlantic growers by a commercial processor (Knouse Fruit Products Co., Inwood, WV). This summation was over six grades of apple (U.S. No. 1, 2.75 in. and up; U.S. No. 1, 2.5 to 2.75 in.; U.S. No. 1, 2.25 to 2.75 in.; U.S. No. 2, 2.75 in. and up; ciders; culls). Rejected loads in 1997 and 1998 were valued at three different price levels: (i) commercial processor prices (a scenario in which the producer would return with the same apples and, due to sampling variation, the second federal inspection would not result in a rejected load); (ii) all apples in the load valued at the cider price (a scenario in which the producer would return with the same apples and the fruit were accepted for juice regardless of the damage levels); and (iii) complete loss assumed (i.e., zero price for all apples in the rejected load). Although all three scenarios occurred, the second was the most likely. Commercial processor prices for different grades of fruit are determined annually by individual processing companies.

Costs of pesticide application were computed by management program and by cultivar. Prices of chemicals were obtained from actual purchases made by WVU and price quotes from chemical suppliers $\mathrm{Ag}$ Chemical and Helena Chemical Company (Winchester, VA). All prices were adjusted to 1997 using the USDA agricultural chemical price index. The cost of airblast spraying was computed to be $\$ 13.18 / \mathrm{ha}$ based upon machinery and labor costs for a 32-ha orchard operation (10). The costs of cultural practices were not included in this analysis.

Net revenue computations at each price level for rejected loads were computed as gross revenue minus chemical and pesticide application costs. Net revenue was computed annually on a per-hectare basis for each cultivar under alternative and conventional management. Net present values (NPV) were computed as a summation of net revenues for each year between 1995 and 1998, discounted to 1995 as a base year. NPV served as a measure of profitability for apple production over the 4-year time period. A $4 \%$ interest rate was used in discounting net revenues to their 1995 present value. This interest rate was derived from internal rate of return calculations for processing apples in the midAtlantic region (10). Comparisons of mean NPV were made by cultivar ( 3 observations per cultivar per program) and by management program (12 observations per program).

\section{RESULTS}

Arthropod pests and natural enemies. The incidence of spirea aphids was lower in the alternative management treatment in all 4 years of the study, whereas leafhoppers and European red mites were lower in 1996, 1997, and 1998, and spotted tentiform leafminer was lower in 1996 (Table 2). Injury from oriental fruit moth in 1996 and Japanese beetle in 1995 and 1996 did not differ between management treatments; Japanese beetle caused more injury in the alternative management plots in 1997 (Table 2), and in particular on Liberty (significant management-cultivar interaction, $P=0.002$ ). Arthropod natural enemies were more abundant in the alternative program in both 1996 and 1998 (Table 2), primarily because of significantly higher numbers of ladybird beetles (almost entirely Harmonia axyridis) and green lacewing. In 1996, ladybird beetles were more abundant on Fuji ( 0.4 per terminal) than Golden Delicious (0.17) and York (0.10), whereas green lacewings were more abundant on Liberty ( 0.07 per terminal) than Fuji (0.03) and York (0.03). In 1998, incidence of natural enemies was higher on Fuji (3.0 per terminal) than on Golden 
Delicious (1.6) and York (1.9) in early June, but there were no differences among cultivars in late June.

In harvested fruit, total insect injury was significantly higher in the alternative treatment in 1995 and 1998, but not 1997 (Table 3). In 1995, this difference was due to higher levels of injury from tufted apple bud moth or redbanded leafroller, codling moth or oriental fruit moth, plum curculio, and apple maggot in the alternative plots (Table 3), and in particular on York (significant management program-cultivar interaction, $P=0.004$ ). Even though total injured fruit was similar in each management treatment in 1997, injury from codling moth or oriental fruit moth and tarnished plant bug was higher in the alternative plots (Table 3). In 1998, there was twice as much injury in the alternative than in the conventional management program (Table 3). This was the result of significantly higher levels of injury from codling moth or oriental fruit moth, plum curculio, and apple maggot in the alternative plots. There was no significant difference between management programs in injury caused by tufted apple bud moth or redbanded leafroller and tarnished plant bug.

Diseases. Incidence of apple scab on leaves was similar between treatments when measured in June of each year (data not shown), and was higher in the alternative plots in September in only 1 of the 4 years (September 1995, mean of $12.1 \%$ versus $8.5 \%$ in the alternative and conven- tional plots, respectively, $P=0.05$ ). Powdery mildew incidence was similar between programs in all years except 1995, when it was $2.9 \%$ in the conventional plots and $1.5 \%$ in the alternative plots. Incidence of cedar-apple rust was less than $0.5 \%$.

At harvest in 1995, 1997, and 1998, total diseased fruit was significantly higher in the alternative treatment $(87 \%)$ compared with the conventional treatment $(22 \%)$. Incidence and severity of fruit scab were similar between treatments; however, in alternative plots, both incidence and severity of sooty blotch and flyspeck exceeded that found in the conventional treatment (Table 4). Incidence of rots was higher in the alternative treatment in 1995 and 1997 , but not in 1998. Rot severity was slightly higher in alternative plots in 1997 and 1998, but was similar between treatments in 1995. Among cultivars, levels of total diseased fruit were similar. Incidence of fruit scab was similar among cultivars (i.e., not significantly different from $0 \%$ on Liberty), whereas scab severity was significantly higher for the other three cultivars compared with Liberty. Incidence of flyspeck was similar among most cultivars, although severity on Golden Delicious was significantly lower than that on Fuji.

Processor evaluations. Whereas the alternative treatment yielded numerically larger percentages of US No. 1L in 2 of 3 years, there were few significant differences between treatments in the grading
(Table 5). The percentage of No. 2 fruit in 1997 was $1.1 \%$ from the conventional plots and $0.1 \%$ from the alternative plots. The alternative had higher levels of culls in 1995 and 1998; however, in 1997, this difference was reversed $(5.2 \%$ for conventional versus $3.7 \%$ for alternative). Fruit from the alternative plots exhibited higher levels of bruising in 1995 and 1998 (Table 5). Fruit firmness and brix (percent soluble solids) were similar between treatments over both years, except in 1998, when alternative fruit were slightly softer.

Among cultivars, York yielded the highest number of US No. 1L fruit in both 1995 and 1997, 78.8 and $53.2 \%$, respectively. Fuji and Liberty, but not Golden Delicious, were significantly lower than York for US No. 1L percentage during 1995. All cultivars were similar in the amount of cull fruit, although Liberty exhibited an excessively high percentage in 1997. Golden Delicious had highest bruise percentage in 1995, although only Fuji exhibited significantly less bruise than Golden Delicious. In both years, Liberty and York had the highest pressure values and Fuji exhibited the highest brix.

Economic analysis. Mean apple yields were significantly different between the two management programs only for 1997 data (Table 6). Mean yields for the alternative program were above the state average of $16,128 \mathrm{~kg} / \mathrm{ha}$ in both 1997 and 1998 , whereas conventional program yields were below the state average (15). Among the

Table 3. Incidence (\%) of arthropod pest injury on apple fruit in alternative and conventional management programs ${ }^{2}$

\begin{tabular}{|c|c|c|c|c|c|c|}
\hline Year and treatment & TABM \& RBLR & CM \& OFM & TPB & PC & $\mathbf{A M}$ & Total injured fruit \\
\hline \multicolumn{7}{|l|}{1995} \\
\hline Alternative & $20.6 \mathrm{a}$ & $8.8 \mathrm{a}$ & $4.8 \mathrm{a}$ & $10.9 \mathrm{a}$ & $2.8 \mathrm{a}$ & $41.4 \mathrm{a}$ \\
\hline Conventional & $9.7 \mathrm{~b}$ & $0.3 \mathrm{~b}$ & $1.9 \mathrm{a}$ & $2.4 \mathrm{~b}$ & $0.0 \mathrm{~b}$ & $13.7 \mathrm{~b}$ \\
\hline \multicolumn{7}{|l|}{1997} \\
\hline Alternative & $5.1 \mathrm{a}$ & $1.7 \mathrm{a}$ & $0.6 \mathrm{a}$ & $1.8 \mathrm{a}$ & $\ldots$ & $9.0 \mathrm{a}$ \\
\hline Conventional & $5.8 \mathrm{a}$ & $0 \mathrm{~b}$ & $0 \mathrm{~b}$ & $0.8 \mathrm{a}$ & $\ldots$ & $6.5 \mathrm{a}$ \\
\hline \multicolumn{7}{|l|}{1998} \\
\hline Alternative & $19.7 \mathrm{a}$ & $11.8 \mathrm{a}$ & $4.8 \mathrm{a}$ & $8.5 \mathrm{a}$ & $15.6 \mathrm{a}$ & $52.0 \mathrm{a}$ \\
\hline Conventional & $20.1 \mathrm{a}$ & $0.8 \mathrm{~b}$ & $2.3 \mathrm{a}$ & $0.7 \mathrm{~b}$ & $3.0 \mathrm{~b}$ & $25.1 \mathrm{~b}$ \\
\hline
\end{tabular}

${ }_{\mathrm{z}}$ Each value is the mean of 1,200 fruit from four cultivars combined. TABM $=$ tufted apple bud moth; RBLR $=$ redbanded leafroller; $\mathrm{CM}=$ codling moth $\mathrm{OFM}=$ oriental fruit moth; $\mathrm{PC}=$ plum curculio $\mathrm{TPB}=$ tarnished plant bug; $\mathrm{AM}=$ apple maggot. Different letters in columns denote significant differ ences according to paired $t$ tests $(P<0.05)$.

Table 4. Mean incidence (\%) and severity of scab, flyspeck, sooty blotch, and rots on fruit from alternative and conventional pest management programs ${ }^{\mathrm{z}}$

\begin{tabular}{|c|c|c|c|c|c|c|c|c|}
\hline \multirow[b]{2}{*}{ Year and treatment } & \multicolumn{2}{|c|}{ Apple scab } & \multicolumn{2}{|c|}{ Flyspeck } & \multicolumn{2}{|c|}{ Sooty blotch } & \multicolumn{2}{|c|}{ Rots } \\
\hline & Incidence & Severity & Incidence & Severity & Incidence & Severity & Incidence & Severity \\
\hline \multicolumn{9}{|l|}{1995} \\
\hline Alternative & $3.3 \mathrm{a}$ & $0.8 \mathrm{a}$ & $80.4 \mathrm{a}$ & $1.2 \mathrm{a}$ & $57.2 \mathrm{a}$ & $1.5 \mathrm{a}$ & $21.8 \mathrm{a}$ & $1.4 \mathrm{a}$ \\
\hline Conventional & $1.8 \mathrm{a}$ & $0.7 \mathrm{a}$ & $16.3 \mathrm{~b}$ & $0.9 \mathrm{~b}$ & $3.7 \mathrm{~b}$ & $0.8 \mathrm{~b}$ & $12.2 \mathrm{~b}$ & $1.1 \mathrm{a}$ \\
\hline \multicolumn{9}{|l|}{1997} \\
\hline Alternative & 0 & $\ldots$ & $86.9 \mathrm{a}$ & $2.1 \mathrm{a}$ & $34.8 \mathrm{a}$ & $1.3 \mathrm{a}$ & $25.3 \mathrm{a}$ & $1.5 \mathrm{a}$ \\
\hline Conventional & 0 & $\ldots$ & $3.3 \mathrm{~b}$ & $0.6 \mathrm{~b}$ & $0.2 \mathrm{~b}$ & $0.2 \mathrm{~b}$ & $14.0 \mathrm{~b}$ & $1.0 \mathrm{~b}$ \\
\hline \multicolumn{9}{|l|}{1998} \\
\hline Alternative & $0.3 \mathrm{a}$ & $2.3 \mathrm{a}$ & $85.9 \mathrm{a}$ & $1.8 \mathrm{a}$ & $32.2 \mathrm{a}$ & $1.2 \mathrm{a}$ & $5.6 \mathrm{a}$ & $1.2 \mathrm{a}$ \\
\hline Conventional & $0.2 \mathrm{a}$ & $0.3 \mathrm{a}$ & $16.6 \mathrm{~b}$ & $1.1 \mathrm{~b}$ & $4.8 \mathrm{~b}$ & $0.6 \mathrm{~b}$ & $4.2 \mathrm{a}$ & $0.9 \mathrm{~b}$ \\
\hline
\end{tabular}

${ }^{\mathrm{z}}$ Severity for apple scab is mean number of lesions per infected fruit. Severity for flyspeck, sooty blotch, and rots rated on a 1 -to- 6 scale, where $1=1$ to $10 \%, 2=11$ to $25 \%, 3=26$ to $50 \%, 4=51$ to $75 \%, 5=76$ to $90 \%$, and $6=91$ to $100 \%$ of fruit surface area affected. Mean severity does not include symptomless fruit. Each value is the mean of 1,200 fruit from four cultivars combined. Different letters in columns within years denote significant differences according to paired $t$ tests $(P<0.05)$. 
four cultivars, Golden Delicious had the highest yields and York had the lowest yields.

There was very little difference in application and chemical costs between programs. The present values of per-hectare costs between 1995 and 1998 were \$2,480 and $\$ 2,552$ for the conventional and alternative programs, respectively, over the 4 years. With the exception of 1995, both application and chemical costs were consistently higher each year for the alternative program. One reason for this difference was the added expense of Bt (Biobit and Dipel) being applied every other week beginning at petal fall.

Statistical differences in mean NPV between programs were dependent upon how rejected loads were priced (Table 7). The conventional program had a much narrower range of NPVs (between approximately $\$ 2,400$ and $\$ 2,800 / \mathrm{ha}$ ) compared with the alternative program, where NPV calculations were much more sensitive to rejected load valuation, ranging from over $\$ 4,400$ to just under $\$ 1,100 /$ ha. Mean NPV per hectare was statistically different between management programs when rejected loads were valued at commercial processor prices (Table 7). The alternative program had an NPV $57 \%$ higher than the conventional program. At cider prices, the mean NPVs were essentially the same between the two programs; whereas, at a complete loss for rejected loads, the conventional program had the advantage, being $125 \%$ larger than the alternative, although this difference was not statistically significant.

NPV was calculated by cultivar and program for the three pricing approaches (Table 8). No statistically significant differences were observed between management programs at the cultivar level. Golden Delicious was clearly the most profitable cultivar, with the conventional program yielding higher NPVs for each pricing approach than the alternative program. York was the least profitable cultivar, so that, under the conventional program, NPV was above zero only under the commercial processor pricing approach. Liberty had the least expensive pesticide costs, saving 25 to $30 \%$ compared with the other cultivars under each program. These lower costs were due to lower use of fungicides. However, large financial losses occurred for Liberty in the alternative program when rejected loads were valued at a zero price.

\section{DISCUSSION}

The alternative plots showed lower levels of indirect pests (aphids, leafhoppers, and mites) and increased numbers of arthropod natural enemies. On harvested fruit, there was significantly more injury in the alternative plots from codling moth or oriental fruit moth, plum curculio, and apple maggot. Levels of foliar diseases were similar between treatments; however, fruit from the alternative program exhibited significantly more sooty blotch, flyspeck, and rots. At the commercial processor, levels of cull fruit were higher for the alternative program in 2 of the 3 years with harvestable yield. Loads of fruit that were not acceptable for processing were due mostly to internal worms and worm damage. Incidence of decay was within the quality limits set by the processor, except for one conventional sample, in which decay exceeded 5\%. Of the 36 loads of fruit that were examined from each program, 4 and 13 loads were rejected from the conventional and alternative programs, respectively. NPV comparisons were dependent upon how rejected loads were valued. At cider prices for rejected loads (the most likely scenario), net returns were similar between programs. When rejected loads were valued at a complete loss, conventional NPV was over $140 \%$ higher than the alternative program.

The lower incidence of foliage-feeding pests in the alternative management treat- ment was most likely due to the increased abundance of predators resulting from the lower toxicity spray program using $\mathrm{Bt}$ and oil, in contrast to the higher toxicity of pyrethroid and organophosphate insecticides used in the conventional management treatment. The increased use of oil in the alternative management plots, especially during the early postbloom period, also would have contributed to the lower incidence of European red mites in these plots. Even though there were significant differences in management treatments in foliage pest incidence, populations at or above threshold (12) only occurred with rosy apple aphid in the alternative plots in 1997, and with spirea aphid in the conventional plots in 1997 and 1998. The increased level of fruit injury in the alternative plots from leafrollers (tufted apple bud moth and redbanded leafroller), tarnished plant bug, and plum curculio did not result in downgrading or reduced prices for processing fruit, because most of these surface injuries are removed during peeling. The increased level of injury in the alternative plots from internal fruit feeders, such as codling moth, oriental fruit moth, and apple maggot, is of significant concern and can result in load rejection if internal larvae are found. The alternative management program investigated in this study would need to be strengthened to provide more effective control of internal fruit-feeders in order for fruit to be accepted by the processor on a reliable basis.

The increased abundance of arthropod natural enemies reflects the greater tolerance of these predators to spray applications of $\mathrm{Bt}$ and oil than to the broad spectrum pyrethroids and organophosphates used in the conventional management

Table 6. Total apple production from alternative and conventional pest management programs, 1995 through $1998^{z}$

\begin{tabular}{lcccc}
\hline & \multicolumn{4}{c}{ Apple production $(\mathbf{k g} / \mathbf{h a})$} \\
\cline { 2 - 5 } Treatment & $\mathbf{1 9 9 5}$ & $\mathbf{1 9 9 6}$ & $\mathbf{1 9 9 7}$ & $\mathbf{1 9 9 8}$ \\
\hline Alternative & $4,459 \mathrm{a}$ & 0 & $24,765 \mathrm{a}$ & $17,209 \mathrm{a}$ \\
Conventional & $5,214 \mathrm{a}$ & 0 & $13,995 \mathrm{~b}$ & $14,230 \mathrm{a}$ \\
\hline
\end{tabular}

${ }^{\mathrm{z}}$ Each value is the mean of 12 observations. Different letters in columns denote significant differences according to paired $t$ tests $(P<0.05)$.

Table 5. Apple grades (\%), bruise (\%), pressure (lbs.), and brix (\%) from conventional and alternative pest management programs as determined by a commercial fruit processor ${ }^{\mathrm{y}}$

\begin{tabular}{|c|c|c|c|c|c|c|c|c|c|}
\hline Year and treatment & US No. 1 L & US No. $1 \mathrm{M}$ & US No. $1 \mathrm{~S}$ & US No. 2 & Ciders & Culls & Bruise & Pressure $^{\mathrm{z}}$ & Brix $^{2}$ \\
\hline \multicolumn{10}{|l|}{1995} \\
\hline Alternative & $64.3 \mathrm{a}$ & $23.5 \mathrm{a}$ & $5.2 \mathrm{a}$ & $0.3 \mathrm{a}$ & $3.0 \mathrm{a}$ & $3.7 \mathrm{a}$ & $3.0 \mathrm{a}$ & $18.1 \mathrm{a}$ & $14.8 \mathrm{a}$ \\
\hline Conventional & $59.2 \mathrm{a}$ & $29.3 \mathrm{a}$ & $8.5 \mathrm{a}$ & $0.0 \mathrm{a}$ & $2.2 \mathrm{a}$ & $0.8 \mathrm{~b}$ & $0.7 \mathrm{~b}$ & $18.2 \mathrm{a}$ & $14.2 \mathrm{a}$ \\
\hline \multicolumn{10}{|l|}{1997} \\
\hline Alternative & $30.2 \mathrm{a}$ & $37.6 \mathrm{a}$ & $21.8 \mathrm{a}$ & $0.1 \mathrm{~b}$ & $6.1 \mathrm{a}$ & $3.7 \mathrm{~b}$ & $0.2 \mathrm{a}$ & $21.3 \mathrm{a}$ & $15.4 \mathrm{a}$ \\
\hline $\begin{array}{l}\text { Conventional } \\
1998\end{array}$ & $27.1 \mathrm{a}$ & $37.6 \mathrm{a}$ & $22.7 \mathrm{a}$ & $1.1 \mathrm{a}$ & \multicolumn{4}{|c|}{1998} & $14.8 \mathrm{a}$ \\
\hline Alternative & $55.3 \mathrm{a}$ & $27.4 \mathrm{a}$ & $7.6 \mathrm{a}$ & $0.1 \mathrm{a}$ & $1.3 \mathrm{a}$ & $8.3 \mathrm{a}$ & $0.9 \mathrm{a}$ & $19.6 \mathrm{~b}$ & $14.1 \mathrm{a}$ \\
\hline Conventional & $60.7 \mathrm{a}$ & $26.2 \mathrm{a}$ & $8.4 \mathrm{a}$ & $0.0 \mathrm{a}$ & $0.8 \mathrm{a}$ & $3.8 \mathrm{~b}$ & $0.0 \mathrm{~b}$ & $20.8 \mathrm{a}$ & $14.1 \mathrm{a}$ \\
\hline
\end{tabular}

${ }^{y}$ Each value is the mean of 12 approximately 41-kg (approximately 2-bushel) samples collected from a subset of 10 randomly selected trees from each of four cultivars. Different letters in columns within years denote significant differences according to paired $t$ tests $(P<0.05)$.

${ }^{\mathrm{z}}$ Values for pressure and brix are from 10 fruit/cultivar/treatment from each approximately 41-kg sample. 
treatment. The overall lower level of natural enemies on Liberty than on the other cultivars is difficult to explain. One might assume that lower pest populations would be partly responsible for this occurrence, but this was not the case. There may be other factors associated with this scabresistant cultivar that contributed to lower levels of natural enemies.

Differences in fruit injury levels between management programs are a reflection of differences in efficacy and spectrum of activity of the spray programs. The higher levels of injury from plum curculio and apple maggot in the alternative program are not surprising because $\mathrm{Bt}$ does not kill these pests. Although Bt and oil would have some efficacy against codling moth or oriental fruit moth, the level of control was significantly less than that provided by the organophosphate insecticides in the conventional management program. In our alternative program, Bt was used in 9 to 11 applications at 1.1 $\mathrm{kg} / \mathrm{ha}$ on the same spray schedule as conventional organophosphates. Brunner and Smith (6) found that 12 applications of $\mathrm{Bt}$ (Dipel) at this rate were less effective for the control of codling moth than either 6 or 12 applications of an organophosphate insecticide. However, there was no significant difference in the control where another Bt (Javelin) was applied at $3.3 \mathrm{~kg} / \mathrm{ha}$.

In a laboratory evaluation, horticultural mineral oils have been demonstrated to provide ovicidal activity against codling moth when applied directly to the eggs (13). In a field study consisting of two applications of oil (the same rate as in the present study) against the first generation of codling moth, fruit injury was significantly less than in untreated plots, but higher than in a two-spray program of organophosphate (11).

The above laboratory and field studies (11) were conducted in a semi-arid climate. Higher humidity and rainfall in the eastern United States would make it more difficult to obtain commercially acceptable control of codling moth with Bt and oil. Application rates would have to be increased and spray intervals shortened to approach acceptable control, which would probably be cost prohibitive. In addition, infestation

Table 7. Mean net present value (NPV) per hectare from 1995 to 1998 for each program based on three different prices for rejected loads $^{\mathrm{z}}$

\begin{tabular}{lcc}
\hline & \multicolumn{2}{c}{ NPV (\$ per ha) } \\
\cline { 2 - 3 } Pricing & Alternative & Conventional \\
\hline Commercial & & \\
processor price & $4,458 \mathrm{a}$ & $2,825 \mathrm{~b}$ \\
Cider price & $2,656 \mathrm{a}$ & $2,721 \mathrm{a}$ \\
Zero price & $1,091 \mathrm{a}$ & $2,461 \mathrm{a}$ \\
\hline
\end{tabular}

${ }^{\mathrm{z}}$ Each value is the mean of 12 observations. Different letters in rows denote significant differences according to paired $t$ test $(P<$ $0.05)$. from an adjacent abandoned orchard was a possible contributing factor in the poor performance of the alternative management program against these pests. The removal of most of the abandoned orchard should alleviate this problem in future studies. Comparable control, although poor, of leafroller species (tufted apple bud moth and redbanded leafroller) was provided by the two management programs. Bt has typically performed better against leafrollers than against codling moth due to leafrollers' increased foliage-feeding activity, which provides more opportunity to acquire the toxicant before fruit injury occurs. Fruit injury from leafrollers and codling moth or oriental fruit moth can occur until harvest of a particular cultivar. The higher level of injury from these pests on Fuji would have been due, in part, to the late maturity of this cultivar, because harvest occurred approximately 1 month after the final spray application. Liberty experienced more injury from tarnished plant bug than the other cultivars. This insect is attracted to the developing fruit buds, and the fact that this cultivar develops earlier in the season than the others may have contributed to this increased level of injury. Apple maggot tends to favor early-maturing and thin-skinned cultivars, which may explain the higher level of injury on Golden Delicious as compared with the other cultivars. Injury from apple maggot also is easier to detect on the yellow-colored Golden Delicious than on the other, red-colored cultivars.

The high level of injured fruit in the alternative management treatment in 1998 was at least partly due to the climatic factors and tree size. The mild winter of 1997 to 1998 resulted in high populations of most fruit insects at the beginning of the season. Warmer temperatures throughout the season resulted in tree and insect development that was about 10 to 14 days ahead of normal. This resulted in at least a partial additional generation of codling moth and oriental fruit moth that led to late-season fruit injury. Based on tree-rowvolume calculations, pesticides had been applied at $50 \%$ of full recommended rates in the study orchard since 1995 . There was abundant rainfall during the first half of the 1998 growing season, which provided ideal conditions for tree growth. Because of increased tree size, pesticide application rates were probably marginal for efficacy against many insect pests in 1998. Despite these factors, which may have contributed to less effective pest control in both management programs, an improved alternative management program will need to be developed for internal worm species to prevent the rejection of fruit by processors.

Calcium chloride has been shown to be moderately effective at suppressing fungal diseases in a number of host-pathogen systems $(2,4,8,9)$. Preliminary and ancillary field studies with calcium chloride in controlled experiments have shown that this salt suppresses apple scab, cedar-apple rust, and bitter rot fungi $C$. gloeosporioides and $C$. acutatum $(2,4)$. The suppressive effects of calcium chloride are more likely to occur under low inoculum conditions, such as occur with apple scab in well-managed orchards and with bitter rot in years with normal temperatures and light to moderate rainfall. Calcium chloride has minimal activity against the sooty blotch and flyspeck pathogens; the incidence of these diseases is as high in calcium-treated plots as in nontreated, control fruit, although with some reduction in disease severity (A. R. Biggs, unpublished data). There is no information on the sensitivity of the white rot and black rot pathogens, $B$. dothidea and $B$. obtusa, respectively, to calcium salts. The incidence of rot as determined by the federal inspections in the present study fell generally within the guidelines of the processing apple industry (3 to 5\% incidence of fruit with at least one rot lesion greater than $2.5 \mathrm{~cm}$ in diameter). We observed higher levels of rot in fruit from alternative plots in our laboratory assessments; however, we did not deter-

Table 8. Mean net present value (NPV) calculations between 1995 to 1998 on a per-hectare basis by program, cultivar, and pricing of rejected loads ${ }^{\mathrm{z}}$

\begin{tabular}{lccc}
\hline & \multicolumn{3}{c}{ Mean NPV for rejected loads (\$ per ha) } \\
\cline { 2 - 4 } Cultivar, program & Commercial processor price & Cider price & Zero price \\
\hline Golden Delicious & 6,279 & & \\
Alternative & 6,378 & 4,767 & 4,010 \\
Conventional & 3,710 & 6,378 & 6,378 \\
Fuji & 1,028 & 2,934 & 2,409 \\
$\quad$ Alternative & & 1,028 & 1,028 \\
Conventional & 6,189 & 2,889 & $(1,541)$ \\
Liberty & 3,866 & 3,640 & 2,842 \\
Alternative & & & \\
Conventional & 1,654 & 454 & $(515)$ \\
York & 29 & $(161)$ & $(403)$ \\
Alternative & & & \\
Conventional & & & \\
\hline
\end{tabular}

${ }^{\mathrm{z}}$ Each value is the mean of three observations. Values in parentheses denote negative net present values. NPV within columns by cultivar are not significantly different according to paired $t$ tests $(P$ $<0.05)$. 
mine the proportions of rot caused by the different organisms. One concern is that, even though fruit from the alternative treatments could be sold for processing in most years, they would be more likely to develop postharvest disease symptoms. Furthermore, there is an inherent risk in the use of calcium chloride alone to suppress fungal diseases, because it apparently is not effective under conditions of warm temperatures, high rainfall, and high inoculum levels, as were experienced in 1997.

With only limited years of apple production data, the conclusions from this research are tentative. Although this study found no conclusive evidence of a greater percentage of culls in the alternative plots, total diseased fruit was significantly higher in the alternative program compared with the conventional program in all years. Despite reduced pesticide use, pest management costs were approximately 3\% higher in the alternative program over the 4 years of the study. This result was attributed to the expense and number of applications of Bt (Biobit and Dipel), as well as additional late-season applications of calcium chloride for Fuji and York. NPV calculations for 1995 to 1998 showed little difference between the two programs when rejected loads received cider prices (the most realistic of the three pricing scenarios). However, if rejected loads were valued at a complete loss, then the conventional program was clearly more profitable than the alternative, with Golden Delicious yielding the largest net returns among the four cultivars.

\section{ACKNOWLEDGMENTS}

We thank D. Leach, T. Winfield, J. Wood, I. Myers, A. Hervani, and J. Murphy for technical assistance; and K. Burkhart, Knouse Foods Cooperative, for providing advice and assistance throughout the course of this study.

\section{LITERATURE CITED}

1. Baugher, T. A., Singha, S., and Leach, D. W. 1992. West Virginia slender spindle. W. V. Univ. Coop. Ext. Serv. Circ. OM113.

2. Biggs, A. R. 1999. Effects of calcium salts on apple bitter rot caused by two Colletotrichum spp. Plant Dis. 83:1001-1005.

3. Biggs, A. R., Baugher, T. A., Kotcon, J. B., Glenn, D. M., Collins, A. R., Sexstone, A. J., Hogmire, H. W., Byers, R. E., and Lightner G. W. 1997. Growth of apple trees, nitrate mobility and pest populations following a corn versus fescue crop rotation. Am. J. Alt. Agric. 12:162-172.

4. Biggs, A. R., Ingle, L. M., and Solihati, W. D. 1993. Control of Alternaria rot of Nittany apple fruit with calcium chloride and fungicides. Plant Dis. 79:976-980.

5. Biggs, A. R., Kotcon, J. B., Baugher, T. A., Collins, A. R., Glenn, D. M., Hogmire, H. W., Byers, R. E., Sexstone, A. J., and Lightner, G. W. 1994. Comparison of corn and fescue rotations on pathogenic nematodes, nematode biocontrol agents, and soil structure and fertility on an apple replant site. J. Sustain. Agric. 4:39-56.

6. Brunner, J. F., and Smith, L. O. 1993. Apple, codling moth control with Bacillus thuringiensis, 1991. Insectic. \& Acaricide Tests 18:6.

7. Byers, R. E., Hogmire, H. W., Ferree, D. C.,
Hall, F. R., and Donohue, S. J. 1989. Spray chemical deposits in high-density and trellis apple orchards. HortScience 24:918-920.

8. Conway, W. S., Sams, C. E., Abbott, J. A., and Bruton B. D. 1991. Postharvest calcium treatment of apple fruit to provide broadspectrum protection against postharvest pathogens. Plant Dis. 75:620-622.

9. Conway, W. S., Sams, C. E., McGuire, R. G., and Kelman A. 1992. Calcium treatment of apples and potatoes to reduce postharvest decay. Plant Dis. 76:329-334.

10. Funt, R. C., Baugher, T. A., Hogmire, H. W. and Kleiner, W. C. 1992. Profitability of different apple orchard systems in the eastern United States. Hortic. Dep. Ser. 624, Ohio Agric. Res. Dev. Center, Wooster.

11. Hilton, R., and VanBuskirk, P. 1999. Control of codling moth with first and second cover IGR applications in combination with Orchex 796 horticultural spray oil, 1997. Arthropod Manage. Tests 24:47-48.

12. Hogmire, H. W. 1995. Mid-Atlantic Orchard Monitoring Guide. Natural Resources, Agriculture, and Engineering Service, NRAES-75, Ithaca, NY.

13. Riedl, H., Halaj, J., Kreowski, W., Hilton, R., and Westigard, P. 1995. Laboratory evaluation of mineral oils for control of codling moth (Lepidoptera:Torticidae). J. Econ. Entomol. 88:140-147.

14. Steiner, P. W. 1990. Predicting apple blossom infection by Erwinia amylovora using the Maryblyt model. Acta Hortic. 273:139148.

15. West Virginia Agricultural Statistics. 1998. W. V. Dep. Agric. Off. Agric. Stat. Charleston.

16. Wilcox, W. F., Wasson, D. I., and Kovach. J. 1992. Development and evaluation of an integrated, reduced-spray program using sterol demethylation inhibitor fungicides for control of primary apple scab. Plant Dis. 76:669-677. 